\title{
A revista Ciência Hoje das Crianças em atividades de leitura e escrita em aulas de ciências: análise discursiva de uma metodologia de ensino em relação ao letramento científico
}

\section{Tatiana Galieta}

Universidade do Estado do Rio de Janeiro

tatigalieta@gmail.com

\section{Carolina Suisso das Chagas Ferreira}

Escola Municipal José do Patrocínio, Secretaria Municipal de Educação do Rio de Janeiro carolinasuisso@gmail.com

\section{Resumo}

No artigo descrevemos e analisamos uma metodologia de ensino ("Roda do conhecimento") que tem como ponto de partida a leitura de textos de divulgação científica. A partir do referencial teórico-metodológico da Análise de Discurso, investigamos as condições de produção e os processos de interpretação e autoria de textos por meio de entrevista com o professor e análise das produções escritas dos alunos. Os resultados apontam que os alunos não atingem o nível de repetição histórica que os constituiria como autores que mais reproduzem do que se posicionam frente aos textos lidos, o que compromete o letramento científico. Concluímos que a metodologia de ensino está limitada às fronteiras pré-estabelecidas do discurso científico escolar por estar inscrita em uma formação discursiva altamente estável, relacionada à autoridade do discurso científico, que é reforçada nas aulas de ciências por meio da restrição dos sentidos.

Palavras-chave: Educação em Ciências, Leitura e escrita, Letramento científico, Metodologia de ensino; Textos de divulgação científica.

\section{Reading and writing in science education: discursive analysis of a teaching methodology related to scientific literacy}

\begin{abstract}
In the paper we describe and analyze a teaching methodology ("Wheel of Knowledge") that has as its starting point the reading of popular science texts. From the theoretical and methodological framework of Discourse Analysis investigate the conditions of production and interpretation processes and authorship of texts through interviews with the teacher and analysis of written productions of students. The results show that students do not reach the historical repetition level that would be as authors that more than reproduce position themselves before the read texts, which compromises the scientific literacy. We conclude that the teaching methodology is limited to preestablished borders of school scientific discourse to be entered in a highly stable discursive formation, related to the scientific discourse authority, which is enhanced in science classes by restricting


Keywords: Science Education, Reading and writing, Scientific literacy, teaching methodology; Popular Science Texts.

\section{Letramento científico: relações entre os processos de leitura e escrita de textos de divulgação científica}

O ensino de ciências tem assumido diferentes funções e objetivos desde sua implementação enquanto disciplina escolar no currículo da educação básica brasileira, atendendo a demandas internacionais e nacionais que ora se aproximam das ciências acadêmicas de referência, ora estão em sintonia com finalidades sociais e utilitaristas da Ciência no cotidiano do estudante (KRASILCHIK, 2000; MARANDINO et al., 2009). Mais recentemente, tem ganhado força entre a comunidade de pesquisadores em Educação em Ciências a ideia de que aprender ciências compreende reconhecer o papel social da ciência e suas interações com os aspectos políticos, históricos, econômicos e éticos. Desta forma, o exercício de práticas sociais que usam o conhecimento científico e tecnológico - tendo como alvo a tomada de decisões e relacionado à compreensão da linguagem da ciência - vem sendo colocado como o objetivo central do letramento científico (LC) no âmbito do ensino formal (SANTOS, 2006).

Entendemos que, dentre as várias práticas sociais com as quais os professores de ciências estão diretamente envolvidos, a leitura e a escrita são processos fundamentais a ser desenvolvidos em sala de aula tanto para a aquisição da linguagem científica quanto para a aprendizagem de conhecimentos científicos. Entendemos que ensinar ciências consiste em inscrever o sujeito em uma estrutura social - a da ciência ensinada na escola - levando em conta que tal estrutura está fortemente influenciada pelo aspecto fundamental da escrita nas ciências e, portanto, pela linguagem científica escolar. Em outras palavras, para se inscrever na estrutura social da ciência que se ensina na escola, o sujeito precisa dominar a leitura e a escrita praticadas nas aulas de ciências. $\mathrm{Na}$ visão de Santos (2009), as habilidades de leitura e escrita encontram-se intimamente relacionadas com um ensino de ciências comprometido com reflexões em torno das relações entre Ciência, Tecnologia e Sociedade (CTS) que visa à promoção do LC para a mudança de visão de mundo e sua devida leitura crítica pelo educando.

Em trabalhos recentes (FERREIRA; GALIETA, 2014; 2015), analisamos as relações entre leitura e escrita em artigos resultantes de uma revisão de literatura que foram publicados em periódicos nacionais de Educação em Ciências e que abordam esses processos dentro de uma perspectiva de LC. Apesar de os 21 artigos encontrados tratarem da leitura e da escrita no Ensino de Ciências como uma dimensão do LC, essa relação aparece como objeto de estudo em apenas três 
deles, o que demonstra que este ainda é um tema pouco investigado no Brasil pelos pesquisadores da área. O principal resultado encontrado por meio deste levantamento consiste em que muitas das publicações que consideram o papel da escrita/leitura no Ensino de Ciências e fazem referência ao LC, estabelecem vínculos superficiais entre essas duas perspectivas (LC - leitura/escrita) ou consideram apenas a associação entre a aprendizagem de ciências $e$ de leitura/escrita na língua materna e não a questão da especificidade da aprendizagem da leitura e da escrita nas ciências. Por outro lado, a análise dos trabalhos em que a escrita e/ou a leitura são objetos empíricos revela a possível existência do pressuposto implícito de que a habilidade de ler/escrever quando o conteúdo é científico difere da habilidade de ler/escrever outros temas e que isso estaria relacionado à preferência por determinados gêneros textuais no âmbito do ensino das ciências.

A partir desta revisão, buscamos aprofundar a relação entre a leitura, a escrita e o LC, a partir do olhar teórico discursivo sobre os processos de leitura e de escrita e do conceito de LC dentro de uma perspectiva crítica e humanística (SANTOS, 2009). Entendemos, portanto, que o leitor tem seu papel subjetivo em destaque quando na interação com um texto de forma que suas histórias de leitura e as condições de produção permitem a produção de uma multiplicidade de sentidos e interpretações (ORLANDI, 1993). Já a escrita é entendida dentro da perspectiva de autoria, quando o sujeito é capaz de tornar as palavras do outro suas próprias palavras, em um processo de repetição histórica (ORLANDI, 1996). Logo, se estamos dizendo que o aluno somente é letrado cientificamente quando ele é capaz de ler e escrever textos científicos, apropriando-se da linguagem científica e posicionando-se criticamente frente às informações científicas com as quais ele tem contato dentro e fora da escola, é fundamental que o professor de ciências crie e execute atividades em sala de aula nas quais os alunos possam exercitar a leitura como processo interpretativo (e não só de memorização) e a escrita como processo de formação de autores de seus próprios discursos (e não apenas de bons copiadores e redatores de textos iguais aos que são lidos, falados ou escritos pelo seu professor em sala de aula).

Nesse sentido, visualizamos o potencial do estabelecimento de relações formais de leitura e escrita dos alunos com textos e discursos sobre Ciência que não são produzidos com o intuito primeiro de circulação em ambiente formais de ensino para o desenvolvimento do processo de LC. Este é o caso de textos de divulgação científica (TDC) como aqueles que compõem cadernos e/ou reportagens em jornais (impressos e eletrônicos), revistas, blogs, fanpages (páginas do Facebook), entre outros meios de comunicação, os quais veiculam notas e opiniões sobre Ciência e Tecnologia. É importante frisar que, em acordo com nosso olhar teórico sobre a constituição de discursos, a divulgação científica (DC) consiste em um gênero de discurso específico que se materializa em textos (escritos, orais, pictóricos, imagéticos) diversos. Desta forma, concordamos com Zamboni 
(2001) ao questionar a DC como sendo meramente uma prática de reformulação do discurso científico e ao compreendê-la como um discurso independente do discurso da Ciência, embora ambos mantenham determinadas relações entre si, ou seja, a DC é vista como uma prática social na qual sujeitos imersos em um dado contexto sócio-histórico comunicam conhecimentos relacionados à Ciência para um público de não especialistas, constituindo uma determinada formação discursiva.

De acordo com essa perspectiva, a DC é considerada um gênero do discurso distinto do gênero discursivo da ciência. Para tanto, utilizamos o conceito de gênero do discurso proposto inicialmente por Bakhtin (1992). Este filósofo da linguagem entende que cada esfera de utilização da língua elabora seus tipos relativamente estáveis de enunciações, os chamados gêneros do discurso, que possuem um caráter sócio-histórico e encontram-se diretamente relacionados a diferentes atividades sociais. Com base nessa definição de gênero do discurso assumimos que a DC não é uma simples tradução de conhecimentos científicos que seriam adaptados a um público que não domina determinados conceitos e procedimentos próprios da ciência. Apesar de ela também realizar a transposição de conhecimentos científicos, ao realizar tal tarefa ela se constitui como um novo gênero do discurso que possui características particulares que dizem respeito a essa nova atividade social. Assim, a DC consiste no resultado de uma atividade discursiva que se desenvolve em condições de produção inteiramente diferentes daquelas em que o conhecimento científico é produzido pelos cientistas. As condições de produção do discurso da DC estão relacionadas com o enunciador/autor, com o destinatário (público não especializado), com o tratamento a ser dado ao assunto e com a construção composicional. Como resultado dessas condições de produção temos a superposição de traços de cientificidade, laicidade e didaticidade, que se deixam mostrar em graus variados na superfície do texto de divulgação (ZAMBONI, 2001).

Ao assumirmos este pressuposto teórico também estamos reconhecendo que a entrada de TDC nas aulas de Ciências é um processo que precisa ser mediado pelo professor, desde o momento da sua seleção, passando pela opção e elaboração de uma dada metodologia de ensino, até o momento em que de fato é introduzido e utilizado em sala de aula. Estudos anteriores debruçaramse sobre a presença da DC em aulas de Ciências buscando investigar as diferentes funções dos TDC na escola, identificadas como: motivação e estímulo à participação dos estudantes, complementação de materiais didáticos, desenvolvimento de habilidades e práticas de leitura, estabelecimento de relações entre a linguagem do estudante e a linguagem científica, contato com valores socioculturais implícitos ou explícitos nas informações presentes em reportagens sobre ciência e tecnologia, possibilidades de se explorar relações CTS, formação de espírito crítico e reflexivo (GALIETANASCIMENTO; REZENDE JUNIOR, 2010). 
Por entendermos que se fazem necessários estudos empíricos que analisem o uso de TDC como recursos didáticos, a mediação feita pelo professor em todo o processo de ensinoaprendizagem e, indo além, pensando nas contribuições de metodologias de ensino que contemplem a leitura e a escrita de TDC voltadas ao LC dos alunos, foi que propusemos o estudo apresentado neste trabalho. Nosso objetivo consistiu em analisar os potenciais de uma metodologia de ensino que utiliza como recurso didático TDC da revista Ciência Hoje das Crianças (CHC) para o desenvolvimento de habilidades de leitura e escrita em aulas de ciências. Descrevemos as etapas desta metodologia, além de caracterizar suas condições de produção por meio do discurso do professor idealizador e de realizar uma análise preliminar de textos escritos de alunos, buscando estabelecer relações entre leitura, escrita e LC. Para tanto, utilizamos como referencial teóricometodológico a Análise de Discurso cujos construtos teóricos e categorias analíticas são apresentados na seção seguinte.

\section{Análise de Discurso: pressupostos teóricos e metodológicos}

A Análise de Discurso (AD) de linha francesa estabelece um objeto diferente daquele instaurado pela Linguística tradicional, uma vez que a linguagem deixa de ser vista apenas como um "meio de comunicação", enquanto instrumento utilizado com o objetivo de comunicar e transmitir informações, passando a ser considerada como mediação, como processo de produção de sentidos, ou seja, em seu funcionamento enquanto discurso. Este, por sua vez, dispõe de formas de apropriação pelo indivíduo falante, do universo da língua, implicando a participação do sujeito na linguagem (ORLANDI, 1983). As formas de apropriação da linguagem estão relacionadas às práticas sociais nas quais o sujeito participa de modo que ele "sabe" o que pode e deve dizer ou deixar de dizer em uma dada conjuntura. Estas “diferentes regiões do dizível para os sujeitos" são nomeadas por Pêcheux (1990) de formações discursivas.

A noção de formação discursiva é básica na $\mathrm{AD}$, "pois permite compreender o processo de produção dos sentidos, a sua relação com a ideologia e também dá ao analista a possibilidade de estabelecer regularidades no funcionamento do discurso" (ORLANDI, 2002, p. 43). Por causa da propriedade fundamental de todo discurso de se constituir no/pelo diálogo com outros discursos (interdiscursividade) é que se entende que toda formação discursiva é heterogênea e atravessada por outras formações discursivas. Os sentidos dependem de relações constituídas nas/pelas formações discursivas que possuem fronteiras fluidas e configuram-se e reconfiguram-se continuamente em suas relações. Ao compreendermos que o discurso possui uma materialidade textual e que o texto se relaciona a uma dada formação discursiva, podemos dirigir nosso olhar analítico sobre o texto 
buscando remetê-lo aos diferentes discursos que o atravessam e o constituem como um gênero específico.

A AD procura, então, descrever, explicar e avaliar criticamente os processos de produção, circulação e consumo dos sentidos os quais se encontram materializados nos textos. Estes são identificados como unidade de discurso, definindo-os como unidades complexas de significação (ORLANDI, 1993). Logo, os textos, ao serem abordados como integrantes de práticas sociais inseridas em contextos determinados, nada mais são do que discursos. Os contextos, por sua vez, referem-se às condições de produção que constituem o sentido da sequência verbal produzida. As condições de produção remetem, em um sentido mais estrito, às condições de enunciação (situação imediata e interlocutores diretamente envolvidos), mas também incluem, em um sentido mais amplo, o contexto sócio-histórico e ideológico (ORLANDI, 2002). Nesta perspectiva, as condições de produção do discurso são, portanto, tudo aquilo que condiciona o que pode e deve ser dito, quem diz, para quem diz, como diz, onde diz e, até mesmo, o que não diz. A noção de condições de produção possibilita pensar aspectos das interações sociais e suas mediações inclusive no caso específico da mediação pela leitura.

A leitura não é compreendida como um ato mecânico, pois a inteligência (ou inteligibilidade) de um texto não pode ser unicamente atribuída ao seu autor. A AD destaca o papel subjetivo do leitor em sua interação com o texto e a impossibilidade de o sentido estar colado à palavra, ou seja, de haver apenas uma única interpretação para aquele determinado texto. Nessa visão de leitura, deixa-se de restringir a interpretação à simples decodificação de signos presentes nos textos para se considerar o papel ativo dos sujeitos envolvidos nesse processo, destacando ainda a dimensão política do ato de ler, já que se consideram os contextos históricos e sociais de sua produção. A leitura consiste, desta forma, no "momento crítico da produção da unidade textual, da sua realidade significante" quando os interlocutores se identificam como tal "e, ao fazê-lo, desencadeiam o processo de significação do texto" (ORLANDI, 1993, p. 9-10).

A leitura está relacionada às diferentes compreensões e interpretações que os sujeitos assumem na medida em que interagem com o texto de modo que um mesmo texto pode vir a ser interpretado de diferentes formas por diferentes leitores, devido ao fato de ser próprio da natureza da linguagem a possibilidade da multiplicidade dos sentidos. Assim, notamos a existência de textos que proporcionam um tipo de leitura chamada parafrásica, ou seja, que "se caracteriza pelo reconhecimento (reprodução) do sentido dado pelo autor", enquanto outros se abrem à possibilidade de uma leitura polissêmica, que "se define pela atribuição de múltiplos sentidos ao texto" (ORLANDI, 1983, p. 187). 
As leituras polissêmicas acontecem por conta dos deslocamentos de sentidos que são possíveis devido ao fato de o sentido não se encontrar inscrito no texto, existindo, portanto, a possibilidade de diferentes compreensões por distintos sujeitos (ORLANDI, 1996). Isso acontece pelo fato de cada leitor possuir diferentes histórias de leitura e, desta forma, construir diferentes intertextos (isto é, tecer relações com textos lidos anteriormente) de modo que o sentido pode ser alargado ou restringido (ORLANDI, 1984). Logo, todo leitor tem sua história de leitura e será exatamente esse conjunto de leituras feitas anteriormente que configurarão, em parte, a compreensibilidade de cada leitor específico.

Outro fator que constitui o processo de leitura diz respeito aos interlocutores envolvidos (autor/texto e leitor). O lugar social por eles ocupado é também parte constitutiva do processo de significação; portanto, o(s) sentido(s) de um texto será(ão) determinado(s) pelas posições que ocupam aqueles que o produzem (os que o emitem e o leem), ou seja, por relações de força (ORLANDI, 1993). Além disso, suas imagens recíprocas determinam não apenas a significação pelo leitor como o próprio processo de elaboração do texto, já que o autor constrói seu texto com base nas expectativas que ele tem de seu leitor, criando, assim, a imagem de um leitor virtual.

De uma forma geral, as condições de produção da leitura incluem os seguintes fatores: situação, contexto histórico-social e interlocutores (ORLANDI, 1983, p. 168). No que diz respeito, especificamente, às leituras feitas na escola, observamos geralmente o exercício de um papel coercitivo do professor nas interpretações possíveis dos alunos, de forma que "o discurso pedagógico não dá importância à compreensão: ou o aluno já tem as condições favoráveis ou ele decora, repete, imita" (ORLANDI, 1983, p. 174). O aluno assume, assim, sua identidade de leitor colocando-se no lugar desejável de interlocutor em sala de aula.

Os professores, segundo Orlandi (1984), são especialistas que legitimam o processo histórico da leitura e que podem ser considerados críticos em determinados domínios científicos. Desta forma, "ao mesmo tempo em que avaliam a importância de um texto, os críticos fixam-lhe um sentido que é considerado o desejado (o prestigiado) para a leitura" (ORLANDI, op. cit., p. 8). É nesse circuito da leitura de prestígio em que atua também o professor de ciências, direcionando a leitura, incentivando a produção de determinados sentidos em detrimento de outros e valorizando determinadas práticas.

O que tem sido valorizado no espaço escolar são determinadas leituras (que se refletem nos textos produzidos pelos alunos) que fazem com que o discurso pedagógico constitua-se como um discurso autoritário (ORLANDI, 1983), baseado em leituras parafrásicas, sem abertura para os deslocamentos de sentidos que certamente acontecem quando no momento da interação entre sujeito e texto e que são propiciados em maior ou menor grau de acordo com o tipo de texto em 
questão. Esta questão da limitação de sentidos que o professor pode imprimir durante a leitura de textos científicos escolares seria constatada, em última instância, nas próprias produções escritas dos alunos. Elas seriam uma das fontes reveladoras dos entendimentos e dos sentidos construídos pelos alunos a partir da leitura de um texto. Certamente que o tipo de texto solicitado pelo professor tenderá a alargar ou restringir as margens das compreensões dos alunos de forma que o discurso materializado nos textos dos estudantes refletirá o nível de apropriação do discurso da ciência (ALMEIDA et al., 2008; GIRALDI, 2010).

É nesse sentido que Orlandi (1996) propõe um conceito de autoria, o qual apenas se consolida quando o sujeito é capaz de tornar as palavras do outro como suas próprias palavras. Esta seria a repetição histórica, na qual o sujeito apropria-se do discurso, interpretando, de modo que o repetível faça parte de sua memória constitutiva (ORLANDI, 1983). Os outros tipos de repetição seriam a mnemônica (aquela próxima à repetição sem reflexão, que pode ser relacionada à memorização dos conceitos científicos, em geral valorizada pelos professores em sala de aula) e a formal (o aluno repete aquilo que leu ou ouviu de maneira um pouco diferenciada, alterando apenas as frases, reproduzindo com outras palavras o mesmo sentido) (ORLANDI, 1983). O sujeito que se torna autor somente o faz a partir da superação da paráfrase (a memória, o dizer que se mantém) e a constituição da polissemia (na qual há o deslocamento, a ruptura, a criatividade) em um processo de repetição histórica. O processo da escrita por alunos em aulas de ciências deveria, então, priorizar a historicização dos sentidos por meio de uma efetiva apropriação do conhecimento científico.

A compreensão da leitura e da escrita como processos de interpretação subjetiva nos ajudam a olhar a sala de aula de ciências de modo a desnaturalizar determinadas práticas e estratégias de ensino executadas pelos professores. Quando estes avaliam textos produzidos pelos alunos - atribuindo-lhes notas ou qualquer outro tipo de juízo de valor - eles estão, de certa forma, normatizando os sentidos que podem e devem ser construídos a partir de uma explicação ou da leitura de um texto. Esta função do professor é altamente desejável no processo de LC, uma vez que ela orienta o aluno na compreensão de fenômenos naturais de acordo com o conhecimento científico e possibilita a visualização de suas repercussões em seu cotidiano, valorizando as práticas sociais inerentes a ele. No entanto, a restrição dos sentidos, os quais se materializam nos textos de autoria dos alunos, pode surtir exatamente o efeito contrário: ele não consegue enxergar nada além do próprio conceito científico, não estabelecendo as relações CTS desejáveis do ponto de vista do LC crítico e humanístico.

\section{Considerações metodológicas da pesquisa}

Em busca da compreensão das condições de produção tanto da metodologia de ensino elaborada 
pelo professor/sujeito da pesquisa, quanto das produções escritas dos alunos a partir da leitura de textos de divulgação científica em aulas de ciências, realizamos uma entrevista semiestruturada com o professor Ézio'. A entrevista semiestruturada, de acordo com Minayo (2012, p. 64), “combina perguntas fechadas e abertas, em que o entrevistado tem a possibilidade de discorrer sobre o tema em questão sem se prender à indagação formulada". Desta forma, poderíamos questionar o sujeito sobre pontos chaves para o entendimento de suas motivações pessoais e histórias de leitura; do contexto de elaboração, desenvolvimento e aplicação da metodologia e do cenário no qual as leituras e as produções escritas se deram, ao mesmo tempo em que o professor pudesse se reportar a memórias interdiscursivas relevantes.

O roteiro da entrevista foi dividido em quatro blocos, os quais abordavam os seguintes assuntos: 1) apresentação dos objetivos da pesquisa pela entrevistadora; 2) delimitação do perfil do professor (formação acadêmica, tempo de magistério e atuação profissional atual); 3) identificação das histórias de leitura e de escrita do entrevistado; 4) entendimento dos objetivos do ensino de ciências e das práticas de leitura e de escrita nas aulas de ciências do entrevistado. A entrevista teve duração aproximada de 1 (uma) hora, foi registrada em áudio e vídeo e apenas os períodos de fala considerados relevantes foram transcritos.

Para a análise da produção textual dos alunos utilizamos o dispositivo analítico para textos escritos relacionados ao discurso científico escolar desenvolvido por Galieta (2014), a partir das considerações de Orlandi (2002), em três etapas:

$1^{\mathrm{a}}$ etapa: Constituição do corpus. A delimitação do corpus segue critérios teóricos e não empíricos (positivistas). O corpus é composto por textos que são as unidades de análise. A função do analista consiste em remeter o texto imediatamente a um discurso de modo a explicitar "suas regularidades pela sua referência a uma ou outra formação discursiva que, por sua vez, ganha sentido porque deriva de um jogo definido pela formação ideológica dominante naquela conjuntura" (ORLANDI, 2002, p. 63). O corpus resulta de uma construção do próprio analista, ou seja, ele é delimitado de acordo com o objetivo do analista, a natureza do material e a pergunta da pesquisa. Esta seleção definirá um corpus bruto, ou seja, “o material de linguagem bruto coletado, tal como existe" (ORLANDI, op. cit., p. 65).

$2^{\text {a }}$ etapa: Descrição do corpus. Segundo Orlandi (2002, p. 60), o dispositivo analítico "deve explicitar os gestos de interpretação que se ligam aos processos de identificação dos sujeitos, suas filiações de sentidos [...]. Nessa empreitada, descrição e interpretação se interrelacionam”. Desta forma, o analista de discurso trabalha no entremeio da descrição com a interpretação. Com a descrição, o corpus bruto começa a tornar-se objeto discursivo, pois o material já recebeu um

\footnotetext{
${ }^{1}$ Os nomes do professor e dos alunos mencionados neste trabalho são fictícios.
} 
tratamento de análise superficial dando início ao processo de "de-superficialização". Nesse processo realiza-se a análise da materialidade linguística: o como se diz, o quem diz e em que circunstância é dito. A etapa descritiva permite a identificação de características textuais mais específicas a partir das quais o analista poderá adentrar ao espaço interpretativo propriamente dito, buscando relações com as formações discursivas que "selecionam" o que foi dito e como foi dito.

$3^{\text {a }}$ etapa: Interpretação do objeto discursivo. Da mesma forma que nas etapas anteriores, na interpretação o analista deve ter como seu ponto de partida e de chegada sua teoria. É a partir dela que ele pode definir o que, no objeto discursivo, interessa ser analisado de acordo com sua pergunta e seu objetivo. Nesta pesquisa, em específico, interessa-nos os constructos teóricos da AD de paráfrase e polissemia, bem como os níveis de repetições (mnemônica, formal e histórica), a partir dos quais pretendemos interpretar os discursos dos sujeitos.

\section{A metodologia de ensino: "Roda do conhecimento"}

A metodologia de ensino denominada "Roda do conhecimento" está centrada em ações que envolvem a leitura de diferentes gêneros textuais (livros didáticos, textos de divulgação científica, enciclopédias) e posterior produção de textos por alunos em aulas de ciências do Ensino Fundamental (EF). A metodologia foi desenvolvida pelo professor Ézio e tem sido aplicada em suas turmas de diferentes séries do EF em escolas públicas do município de São Gonçalo, estado do Rio de Janeiro. Nesta seção, descrevemos as etapas da "Roda do conhecimento" relativas às experiências nas quais o professor utilizou a revista Ciência Hoje das Crianças (CHC) como fonte original textual de consulta.

\section{$1^{\circ}$ momento: contato com a revista $\mathrm{CHC}$}

A turma é organizada em torno de um círculo e no centro são dispostas diferentes edições da revista CHC. O professor explica a dinâmica da atividade solicitando que os alunos escolham, individualmente, um exemplar de acordo com seu interesse pessoal (Figura 1). Frisamos que o professor, em momento algum, interfere neste processo de escolha (sugerindo algum tema ou conteúdo científico), estimulando a autonomia, algo que ele comenta durante a entrevista.

Figura 1: Turma de $7^{\circ}$ ano na "Roda do conhecimento" no início da atividade

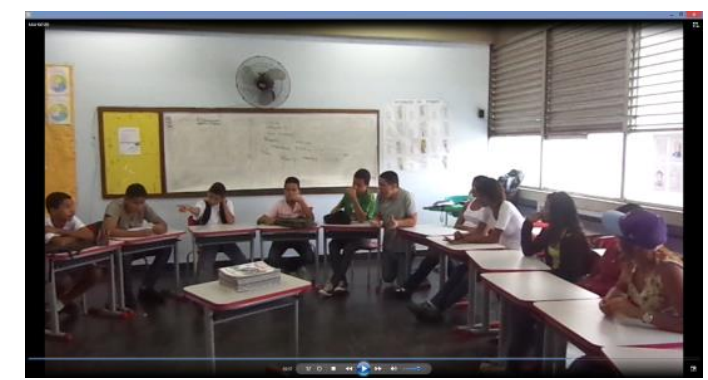

Fonte: Elaborada pelas autoras. 
$2^{\circ}$ momento: escolha e leitura dos textos da revista $\mathrm{CHC}$

Após a explicação da dinâmica, o professor solicita aos alunos que escolham, individualmente, as revistas. Cada aluno deve selecionar uma reportagem de interesse pessoal e realizar silenciosamente a leitura (Figura 2).

Figura 2: Alunos fazendo a leitura da revista $\mathrm{CHC}$ na roda

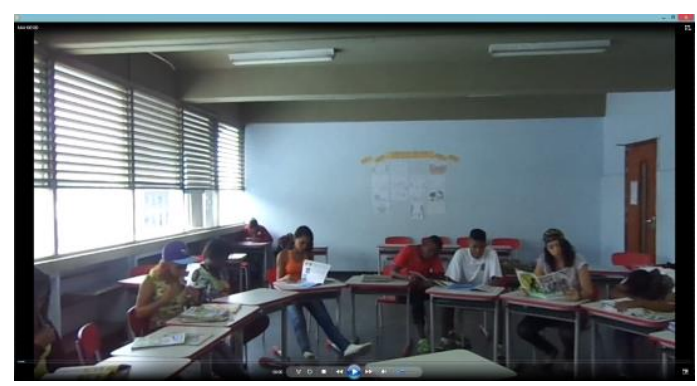

Fonte: Elaborada pelas autoras.

\section{$3^{\circ}$ momento: redação de textos a partir das reportagens da $\mathrm{CHC}$}

Após a leitura, o aluno deve elaborar duas questões relativas ao conteúdo do texto da CHC escolhido e lido. O registro escrito é feito no próprio caderno do aluno (conforme ilustrado na Figura 3). Na etapa de redação das perguntas, o professor não realiza qualquer tipo de interferência. De posse das questões elaboradas pelos alunos $\left(\mathrm{PE}^{2}{ }^{2}\right.$ ), o professor então faz a correção das mesmas, tanto do ponto de vista conceitual (científico) quanto gramatical e ortográfico. É importante ressaltar que o professor recolhe as PE1, leva-as para casa e realiza as correções e modificações em outro momento que não aquele em que os alunos produziram seus registros escritos em sala de aula.

Figura 3: Exemplo de texto da revista $\mathrm{CHC}$ escolhido por aluna do $7^{\circ}$ ano

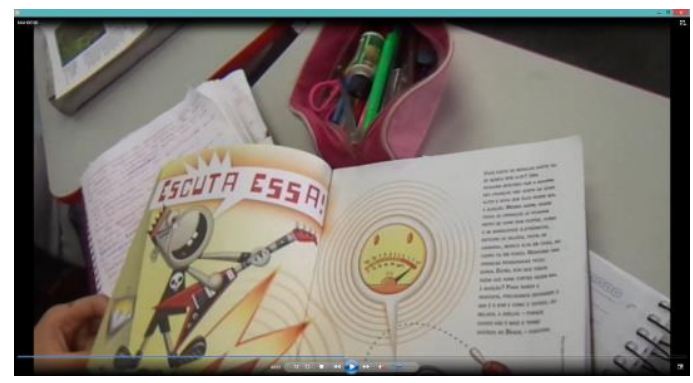

Fonte: Elaborada pelas autoras.

$4^{\circ}$ momento: jogo com as perguntas elaboradas pelos alunos

O jogo que acontece na "Roda do Conhecimento" - em aula posterior - é feito a partir das perguntas elaboradas pelos alunos, corrigidas pelo professor e adaptadas de modo a facilitar sua

\footnotetext{
${ }^{2}$ As produções textuais escritas resultantes da metodologia foram denominadas como PE1 (produção escrita dos alunos sem qualquer modificação do professor), PE2 (produção escrita dos alunos após a primeira correção do professor; questões que passaram a integrar o jogo) e PE 3 (produção escrita reelaborada e revista conceitualmente pelo professor; questões que compunham a prova).
} 
dinâmica (PE2). Ele tem início com a turma sendo dividida em grupos (os alunos de um mesmo grupo ocupam lugares próximos na roda) (Figura 4). Determinado grupo sorteia uma das perguntas, cujo enunciado e suas três opções de respostas são lidos em voz alta pelo professor. Caso o grupo acerte a opção correta, ele marca 1 (um) ponto. Após todas as perguntas terem sido sorteadas e respondidas em igual número por todos os grupos é feita a contagem final dos pontos de modo a consagrar um (ou mais) grupo(s) vencedor(es). É importante ressaltar que todos os alunos que participam do jogo ganham pontos extras na média bimestral, independente de terem integrado o grupo vencedor.

Figura 4: Turma de $8^{\circ}$ ano participando do último momento da roda ${ }^{3}$

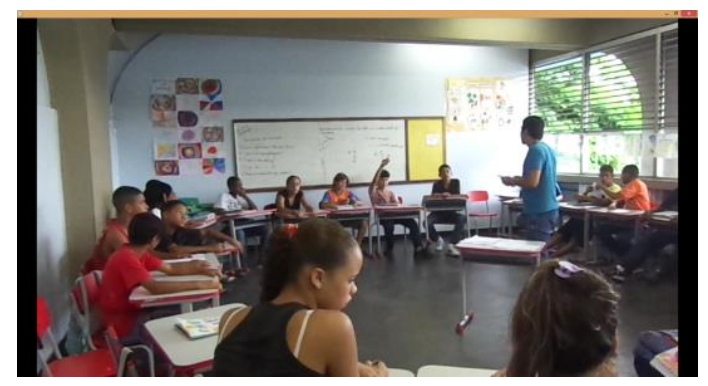

Fonte: Elaborada pelas autoras.

Em aulas seguintes, o professor retoma os temas abordados nas questões, explicando determinados conceitos científicos, e distribui aos alunos uma folha com algumas questões selecionadas. Posteriormente, ele aplica uma prova contendo as questões (PE3) que integraram o jogo e compunham esta folha, porém reformuladas com maior rigor conceitual.

\section{As condições de produção dos discursos}

$\mathrm{Na}$ entrevista feita com o professor Ézio, buscamos compreender suas histórias de leitura e escrita, identificar seus principais objetivos com relação ao ensino de ciências, além de explorar e esclarecer aspectos específicos da metodologia de ensino, de modo a estabelecermos as condições de produção da prática docente do sujeito da pesquisa, bem como aquelas que influenciaram a produção textual dos alunos. Assim, realizamos os primeiros movimentos interpretativos sobre o discurso do professor, organizando-os em três pontos centrais: 1) sua trajetória escolar e acadêmica voltada para suas histórias de leitura e escrita; 2) seus objetivos e expectativas sobre o ensino de ciências e as contribuições da "Roda do Conhecimento" para alcançar tais objetivos; 3) o contexto de produção dos sentidos pelos alunos no âmbito da "Roda do conhecimento".

\footnotetext{
${ }^{3}$ A reprodução das imagens dos alunos foi autorizada por seus responsáveis em Termo de Consentimento Livre e Esclarecido contendo os objetivos da pesquisa.
} 
O professor Ézio graduou-se na licenciatura em Ciências Biológicas em uma universidade particular do Estado do Rio de Janeiro e tem atuado no magistério antes mesmo da conclusão de seu curso e atualmente possui 14 anos de experiência no magistério da rede pública. Ao ser questionado sobre quais suas principais memórias com relação à leitura e à escrita (na escola e na universidade, mas também em seu lazer, durante sua infância e adolescência), o professor Ézio se remeteu a experiências vividas enquanto aluno de escola pública: a leitura de livros da Série Vagalume (voltados para o público infanto-juvenil), nos quais se inspirou para escrever textos solicitados pela professora, o uso de uma letra de samba enredo (que ele diz ainda se recordar) e a leitura de clássicos da literatura, como Clarice Lispector, todos no âmbito da disciplina escolar de língua portuguesa. Em um momento da entrevista, o professor recordou-se de uma experiência marcante em sua trajetória escolar a qual entendemos que seja condição fundamental para que atualmente a leitura e a escrita sejam consideradas prioridades na sua prática docente.

Uma amiga minha falou uma coisa. [...] Eu fui visitar o espaço de leitura dela num colégio em Niterói. [...]E ela me ensinou assim. Que a primeira coisa que o aluno tem que aprender é a ouvir. Depois de aprender a ouvir, a falar. Depois de falar, ler. Depois de ler, escrever. O que aconteceu comigo, no colégio, foi que quando eu cheguei no colégio me colocaram logo para escrever. Eu repeti duas vezes a segunda série. Eu fiz três vezes a segunda série. [...] E eu prometi para minha mãe que eu nunca mais ia repetir. [O professor chorou neste momento.] E eu fui um aluno mais ou menos na segunda série. Na terceira série eu batalhei bastante. Na quarta série eu fui o melhor aluno. [...]Poxa, mas por que que eu repeti duas vezes a segunda série, caramba? Nunca fui bagunceiro, sempre quietinho [...]. Mas eu podia ter ficado. Tem muitos que ficam. [...] Na alfabetização, primeira série, eu passei sem base. Aí fiquei na segunda série sem base. E fui ficando, fui ficando, fui ficando e ninguém fazia nada para me ajudar. Aí eu caí na mão de uma professora [...] e aí foi uma relação de paixão. E tinham dois alunos muito bons [...] que tinham umas letras assim impecáveis e eu com aquela vontade de passar fiquei perto e imitava as letras deles. [...] E eu consegui por esforço próprio né. Eu acho que não foi muito a escola não. Acho que foi uma questão um pouco de autonomia. Acho que a minha história tem um pouco a ver com isso.

Com relação ao seu interesse pela ciência, o professor atribui o mesmo às aulas de um exprofessor do Ensino Médio (EM) que fazia questionamentos "de natureza filosófica" com os quais ele se identificou e atualmente busca em suas leituras para compreender "o entendimento da vida", de forma que hoje predomina a leitura, em seu cotidiano, de textos de cunho religioso. $\mathrm{Na}$ universidade, ele disse ter feito leituras mais técnicas, voltadas para seu projeto de pesquisa sobre manguezais. Ele se reconhece como alguém que, atualmente, "não é fã da leitura", mas se considera uma pessoa que gosta de ler.

Sobre a escrita, ele diz que escreve pouco e mais a trabalho, porém gosta de escrever poesias com rimas fáceis algo que costuma, inclusive, utilizar em suas aulas. Apesar de se reconhecer como 
alguém que lê e escreve pouco, o professor manifestou - em diversos momentos da entrevista - sua preocupação com a melhoria das habilidades de leitura e de escrita de seus alunos, reconhecendo as dificuldades destes e assumindo explicitamente seu papel enquanto formador de leitores e escritores, mesmo tendo que cumprir o Currículo Mínimo (CM) da Secretaria Estadual de Educação (SEE) do Rio de Janeiro.

\section{Os objetivos do ensino de ciências e da metodologia para o professor}

De acordo com o professor, o principal objetivo do ensino de ciências seria a formação da autonomia de seus alunos entendida por ele como "gostar do conhecimento, querer saber mais pelo saber". Quando questionado sobre como ele procede em sala de aula para alcançar este objetivo ele refere-se ao CM que é abordado em poucas aulas deixando as demais para o uso da revista CHC de modo que os alunos podem escolher os assuntos que lhes interessam e escreverem sobre o que eles entenderam dos textos lidos. Sobre este ponto, especificamente, identificamos na fala do professor uma visão crítica sobre as práticas docentes incentivadas e avaliações que têm sido realizadas sistematicamente pela SEE, de modo que seus objetivos de ensino e seu propósito educacional estão muito bem definidos e são a base para o desenvolvimento de suas metodologias.

Eu gostei um pouco desse negócio de currículo mínimo [...]. Mas eu achei razoável porque meu currículo mínimo tá todo nessa folha aqui [Aponta para uma prova]. Eu direcionei entendeu pro que tá apontado ali. E o restante do tempo todo que me sobra eu faço o que eu acho pertinente. E aí eu entrego as revistas para os alunos e eu deixo eles lerem o que eles quiserem. Tem diversos assuntos né e eu só peço para ele escrever o que entendeu.

[...] Às vezes me sinto um pouco meio assim descompromissado, entendeu? Eu deixo a questão do compromisso formal meio que pra lá para deixar algum momento, apresentar o melhor. E eu recorro aí à estratégia do jogo para dar o currículo mínimo. Essas questões eu boto bem marcado né. Porque se o aluno tiver, desenvolver aquele gosto pela leitura, pelo saber depois o mínimo vai ser o mínimo mesmo.

[...] Porque assim no estado, na prefeitura ninguém vai olhar nada, entendeu? Se eu dou é por uma questão de consciência. Se eu não quiser dar eu não dou. Ninguém vai dizer nada. Isso acontece, eu acho, de uma maneira muito geral. $O$ máximo que pode acontecer, no conselho de classe do estado, "você apresentou o conteúdo mínimo?", você pode dizer que sim ou que não [...]. O que pode acontecer é depois a escola ficar dando uns resultados ruins, não dar os resultados que o estado pede [...] tem algumas avaliações, o SAERJ não sei o que e tal. Mas eu considero isso, acho importante e tudo só que é uma diversidade muito grande para você sabe avaliar de uma maneira só. [...] Tem que ver o aluno de uma maneira mais ampla, mais do que um depositório de conhecimento.

Desta forma, o professor Ézio identifica na "Roda do Conhecimento" uma metodologia eficiente para atingir seus objetivos dentro de suas aulas de ciências no EF, apesar de achar que ao contemplar apenas o CM estaria sendo "descompromissado" pelo fato de seu foco central ser o desenvolvimento das habilidades de leitura. 
Ele descreveu a dinâmica da "Roda do Conhecimento" destacando a ênfase na leitura, na expressão oral (quando os alunos expõem em voz alta para a turma o tema do texto lido) e na produção textual. O professor disse ter observado que vários alunos vêm procurando por interesse próprio, fora da escola e trazendo para as aulas, outros textos e assuntos que não aqueles que surgiram na roda. Com isso, ele reconhece o papel da metodologia para o desenvolvimento da autonomia dos alunos. O professor considera que a "Roda do Conhecimento" é uma experiência bem sucedida, embora ainda apresente resultados modestos, já que começou a ser implementada por ele há cerca de dois anos, mas que tem despertado o interesse dos alunos.

Ficou claro na entrevista que a metodologia surgiu com um formato e este vem sendo constantemente reelaborado, aperfeiçoado e adaptado de acordo com as características de cada turma e as permanentes autoavaliações baseadas em seus resultados e nos desempenhos dos alunos.

\section{O contexto de produção de sentidos pelos alunos}

O professor Ézio expôs durante a entrevista a dificuldade que a maioria dos alunos do EF apresenta com relação à leitura e à escrita, relacionando a mudança de postura tanto de alunos quanto de professores quando há a mudança de segmentos no EF. Atualmente, ele tem aplicado à metodologia da "Roda do Conhecimento" em turmas de $6^{\circ}$ ao $9^{\circ}$ ano de duas escolas públicas e identifica o seguinte perfil do alunado:

Eu participei de uma reunião no colégio no sábado. [...] As professoras do primeiro segmento, os alunos ficam lá de sete e meia às quatro da tarde. As professoras na reunião lá falaram que as crianças não aguentam mais escrever. Ela chega de tarde e as crianças pedem "por favor, não escreve mais não tia". Enquanto é criança eu acho que assim eles vão obedecendo porque parece ser uma autoridade e não sei o que. Mas quando chega no sexto ano aí pronto. Eles começam a ficar independentes, começam a formar juízo de valores, aí a gente fica em maus lençóis. Isso numa escola pública né. Nas escolas em que eu trabalho. Então eu penso que as professoras se esforçam mas o sistema carece demais de investimentos, de formação desses professores, de materiais. As crianças já chegam no sexto ano assim... um pouco desestimuladas. Não querem escrever, não querem ler.

Os dados (produções textuais escritas dos alunos) que são analisados neste trabalho foram coletados no colégio estadual ao qual o professor se refere na passagem acima. A escola fica localizada no município de São Gonçalo, RJ, e seu último IDEB (Índice de Desenvolvimento da Educação Básica), referente ao ano de 2011, foi 3,5 (enquanto a média de sua cidade foi 2,9), sendo que os dados sobre a aprendizagem em Português e Matemática foram, respectivamente, 19\% e $11 \%{ }^{4}$.

\footnotetext{
${ }^{4}$ Porcentagem de alunos com aprendizado adequado ao final do $9^{\circ}$ ano do EF.
} 
Apesar do baixo rendimento dos alunos nas avaliações obrigatórias do governo, o professor identifica o colégio como sendo "um bom local de trabalho" cujos alunos são "interessados e respeitosos". Com relação à direção escolar, ele destaca o apoio para a realização de suas atividades no laboratório de ciências e na sala de vídeo, embora enfrente algumas questões burocráticas para a execução de seu trabalho (como armários e salas frequentemente trancadas e a ausência de um funcionário disponível para a abertura destes espaços, sendo não pouco comum deixar de utilizá-los em virtude deste problema). O professor não costuma estabelecer parcerias sistematizadas com os demais professores de ciências da escola, tampouco com os de outras disciplinas. Recentemente, o colégio passou a integrar o Programa Institucional de Iniciação à Docência (PIBID/CAPES) recebendo 5 (cinco) licenciandos (bolsistas de Iniciação à Docência) do Subprojeto Biologia sob supervisão do professor Ézio e coordenação da primeira autora deste trabalho.

\section{Análise das produções escritas: empregando o dispositivo analítico}

\section{Constituição do corpus}

Os dados coletados no âmbito dessa pesquisa englobaram a produção textual de 10 (dez) alunos resultantes da dinâmica da "Roda do Conhecimento". Neste trabalho, o corpus de análise foi delimitado de acordo com um determinado critério, baseado na questão de pesquisa: quais mudanças textuais acontecem nas produções escritas dos alunos ao longo da execução da metodologia de modo a constituírem diferentes formações discursivas? Para tanto, foram selecionados os textos de 2 (dois) alunos de uma turma de $7^{\circ}$ ano do Ensino Fundamental que constituirão o corpus para procedermos as duas outras etapas do dispositivo analítico. Estes textos foram selecionados por terem participado dos três momentos de produção escrita (PE1, PE2 e PE3), de modo que a análise de suas marcas textuais possibilitará caracterizá-las como formações discursivas específicas.

\section{Descrição do corpus}

Na segunda etapa, de descrição do corpus, buscamos identificar o como se diz, o quem diz e em que circunstância é dito com o intuito de localizar características textuais mais específicas de cada uma das produções escritas dos dois alunos. Para tanto, organizamos a apresentação desses textos nos Quadros 1 e 2 (dos alunos Henrique e Jamile, respectivamente) sendo cada um deles referente a um determinado texto de divulgação científica (TDC) original da revista CHC que foi lido no segundo momento da "Roda do Conhecimento".

As PE1 são produtos dos alunos, elaborados no contexto de uma atividade em sala de aula que possuía um objetivo bem delimitado pelo professor de ciências: a redação de um pequeno 
resumo no qual o aluno deveria expor seu entendimento geral a partir da leitura de um TDC e de duas questões sobre o texto lido para integrarem o jogo da "Roda do Conhecimento", ou seja, as circunstâncias de leitura/interpretação e de confecção das PE1 são altamente coercitivas ainda que o TDC tenha sido escolhido livremente pelo aluno. No entanto, os alunos fazem a opção por demarcar que o resumo foi escrito de acordo com suas próprias compreensões: "Bem eu entendi que..." (Henrique) e "Eu entendo que..." (Jamile). Esta consiste em uma marca textual que acena para a demanda concreta do texto solicitado pelo professor que requer dos alunos que "escrevam aquilo que eles entenderam sobre o texto lido". Desta forma, entendemos que apesar de o professor ter criado uma condição para a abertura à polissemia (já que os alunos deveriam escrever o que entenderam e não apenas copiar ou transcrever o que estava no TDC), não necessariamente discursos polissêmicos poderiam ter emergido já que os sujeitos escrevem (e se inscrevem) dentro de uma formação discursiva que se inscreve em um discurso pedagógico autoritário que se caracteriza pela restrição dos sentidos.

Quadro 1: produções textuais referentes às leituras do aluno Henrique (Revista CHC, Ano 22, n. 208, dez. 2009, “Por que é perigoso passar a mão nos olhos depois de tocar uma borboleta?”, p. 17)

\begin{tabular}{|c|c|c|}
\hline PE1 & PE2 & PE3 \\
\hline 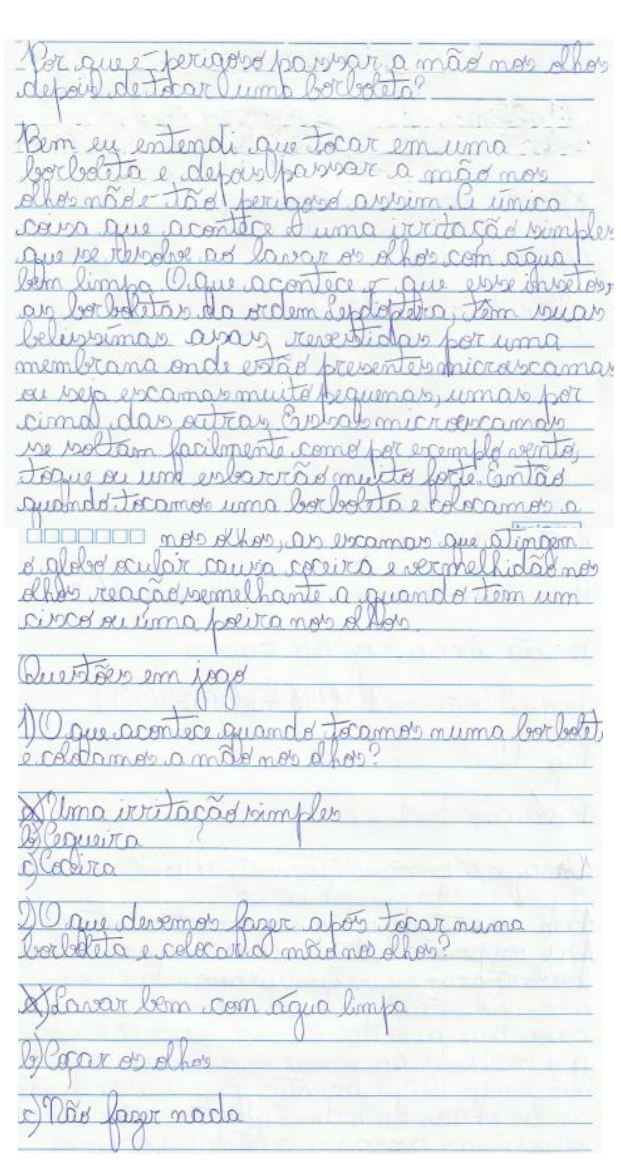 & $\begin{array}{l}\text { As borboletas pertencem ao } \\
\text { reino animal, encontram-se } \\
\text { no grande filo dos } \\
\text { artrópodes, isso por } \\
\text { apresentar um esqueleto } \\
\text { externo e possuir muitas } \\
\text { articulações pelo corpo, } \\
\text { pertence também a classe } \\
\text { dos insetos, em razão de } \\
\text { serem portadoras de três } \\
\text { pares de patas, sabe-se } \\
\text { ainda que as borboletas } \\
\text { pertencem a ordem } \\
\text { lepidóptera devido ao } \\
\text { seguinte fato: } \\
\text { a) Ter o aparelho bucal } \\
\text { sugador. } \\
\text { b) Possuírem três pares de } \\
\text { patas. } \\
\text { c) Possuírem suas asas } \\
\text { constituídas por micro } \\
\text { escamas. }\end{array}$ & $\begin{array}{l}\text { Existe um mito que diz o } \\
\text { seguinte: "Se uma pessoa } \\
\text { tocar as mãos nas asas das } \\
\text { borboletas e depois passar } \\
\text { as mãos nos olhos pode } \\
\text { ficar cega", quando na } \\
\text { verdade, no máximo, pode } \\
\text { ter uma simples irritação. } \\
\text { Tal irritação normalmente é } \\
\text { causada devido: } \\
\text { a) Às pessoas coçarem com } \\
\text { a mão suja. } \\
\text { b) Ao fato das pessoas } \\
\text { esfregarem os olhos com } \\
\text { muita força. } \\
\text { c) Às micro escamas que } \\
\text { podem se desprender das } \\
\text { asas das borboletas e } \\
\text { chegar aos olhos através } \\
\text { das mãos. }\end{array}$ \\
\hline
\end{tabular}

Fonte: Elaborado pelas autoras. 
Quadro 2: produções textuais referentes às leituras da aluna Jamile (Revista CHC, Ano 21, n. 189, abr. 2008, "Você sabia que a banana não nasce de uma semente?", p. 20)

\begin{tabular}{|c|c|c|}
\hline PE1 & PE2 & PE3 \\
\hline 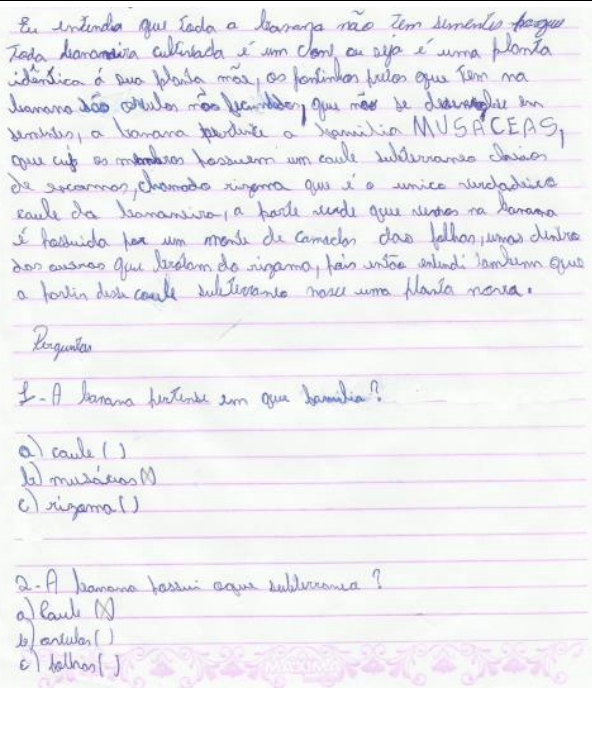 & $\begin{array}{l}\text { As bananeiras pertencem à } \\
\text { família das musáceas, esses } \\
\text { vegetais possuem um caule } \\
\text { chamado de rizoma, que se } \\
\text { caracteriza: } \\
\text { a) Pelo fato de ser formado } \\
\text { pela união de várias folhas } \\
\text { sobrepostas. } \\
\text { b) Por ser um caule } \\
\text { subterrâneo, capaz de se } \\
\text { reproduzir por um processo } \\
\text { de clonagem. } \\
\text { c) Pela capacidade de } \\
\text { sustentar os frutos no } \\
\text { ambiente aéreo. }\end{array}$ & $\begin{array}{l}\text { Que vegetal que pertence à } \\
\text { família das musáceas que } \\
\text { se caracterizam pelo fato de } \\
\text { possuírem um tronco } \\
\text { subterrâneo, o qual } \\
\text { proporciona a capacidade } \\
\text { de reprodução dessas } \\
\text { plantas: } \\
\text { a) Bananeiras } \\
\text { b) Laranjeira } \\
\text { c) Goiabeira }\end{array}$ \\
\hline
\end{tabular}

Fonte: Elaborado pelas autoras.

As PE2 e PE3 sofreram um processo de reelaboração discursiva, uma vez que elas tinham objetivos específicos: comporem o hall de perguntas que seriam feitas em sala de aula, durante o jogo, e, posteriormente, a avaliação escrita bimestral (prova). Logo, a autoria das questões presentes nas PE1 é agora compartilhada entre alunos e professor, uma vez que este promove modificações não apenas conceituais, mas também estruturais, caracterizando as PE2 e PE3 como formações discursivas clássicas relacionadas ao discurso científico escolar que são as provas de múltipla escolha. Podemos, ainda, entender que há uma mudança de contexto de enunciação das questões à medida que as produções escritas são elaboradas, o que pode ser considerado como um movimento de recontextualização discursiva.

No caso dos textos derivados da PE1 do aluno Henrique, percebemos que a PE2 não está diretamente relacionada a qualquer uma das duas questões elaboradas pelo aluno uma vez que se refere ao resumo do TDC, enquanto que a PE3 retoma a primeira questão elaborada pelo aluno, embora haja uma ênfase ao conhecimento científico (referência às micro escamas das asas das borboletas na opção correta).

A questão derivada da PE1 da aluna Jamile e que compõem a PE2 (para o jogo), por outro lado, consiste em uma junção das duas perguntas elaboradas pela aluna ao contemplar a classificação da banana na família das Musáceas e a característica morfológica do caule subterrâneo. Na PE3, notamos que estas informações básicas são mantidas apesar de a questão ser reformulada pelo professor de modo a assumir um formato típico de uma avaliação.

Buscamos explorar as produções escritas dos dois sujeitos-autores na próxima subseção, estabelecendo relações entre os contextos que constituíram e determinaram cada um dos textos, 
além de compreender os movimentos interpretativos entre os textos originais (TDC) e as demais produções a partir dos tipos de repetições encontradas.

\section{Interpretação do corpus}

$\mathrm{Na}$ terceira etapa da análise realizamos a interpretação dos objetos discursivos previamente descritos, os quais se encontram materializados nas produções escritas. Para tanto, voltamo-nos para os textos primários da revista $\mathrm{CHC}$ com o intuito de observar se os alunos realizam repetições históricas (interpretáveis) e não apenas mnemônicas (repetíveis). Encontramos nas PE1 os movimentos interpretativos dos alunos a partir da leitura dos TDC que apresentam referências diretas (paráfrase) aos textos originais da CHC (repetições mnemônicas estão em negrito e repetições formais estão sublinhadas nos Quadros 3 e 4). Por outro lado, leituras polissêmicas também foram encontradas nos registros escritos (PE1) dos dois alunos, demonstrando que, apesar da coerção exercida pelo discurso pedagógico (em funções das solicitações restritivas do professor), houve deslocamentos de sentidos (em itálico nos Quadros 3 e 4).

\section{Quadro 3: exemplos de repetições na produção textual do aluno Henrique}

\begin{tabular}{|c|c|}
\hline TDC & PE1 \\
\hline $\begin{array}{l}\text { Elas são tão coloridas e encantadoras que, de vez em } \\
\text { quando, alguém tem a ideia de pegá-las pelas asas para } \\
\text { observá-las mais de perto. Nessa situação, há quase } \\
\text { sempre um outro alguém passando que grita: - Solte a } \\
\text { borboleta e não coloque as mãos nos olhos, porque é } \\
\text { muito perigoso! } \\
\text { Perigoso é, mas só um pouco, nada grave a ponto de } \\
\text { fazer os olhos doerem horrivelmente ou causar danos à } \\
\text { visão. Podem ocorrer, sim, irritações simples, que são } \\
\text { facilmente resolvidas lavando bem os olhos com água } \\
\text { limpa. Mas, permanece a pergunta: por que isso } \\
\text { acontece? } \\
\text { As borboletas, esses insetos da ordem Lepdoptera, têm } \\
\text { suas belas asas revestidas por uma membrana onde } \\
\text { estão inseridas numerosas microescamas, umas por } \\
\text { cima das outras. É aí que mora o "xis" da questão! } \\
\text { Essas escamas se desprendem facilmente das } \\
\text { membranas das asas, por motivos como vento, } \\
\text { esbarrão ou toque. Então, quando tocamos uma } \\
\text { borboleta, não lavamos as mãos e as levamos aos } \\
\text { olhos, as escamas que atingem o globo ocular } \\
\text { causam coceira e vermelhidão, reação semelhante à } \\
\text { de quando entra cílio, cisco ou poeira em nossos } \\
\text { olhos. } \\
\text { Portanto, para prevenir a irritação causada pelas } \\
\text { escamas das asas das borboletas, vamos combinar de } \\
\text { observar a beleza desses insetos sem tocá-los? Se } \\
\text { concordar, seus olhos estarão em perfeitas condições } \\
\text { para ver o colorido das borboletas à sombra ou ao Sol, }\end{array}$ & $\begin{array}{l}\text { Bem eu entendi que tocar em uma } \\
\text { borboleta e depois passar a mão nos olhos } \\
\text { não é tão perigoso assim. A única coisa } \\
\text { que acontece é uma irritação simples que } \\
\text { se resolve ao lavar os olhos com água bem } \\
\text { limpa. O que acontece é que esse insetos, } \\
\text { as borboletas da ordem Lepdoptera, têm } \\
\text { suas belíssimas asas revestidas por uma } \\
\text { membrana onde estão presentes } \\
\text { microescamas ou seja escamas muito } \\
\text { pequenas, umas por cima das outras. } \\
\text { Essas microescamas se soltam facilmente, } \\
\text { como por exemplo vento, toque ou um } \\
\text { esbarrão muito forte. Então quando } \\
\text { tocamos uma borboleta e colocamos a a } \\
\text { [mão] nos olhos, as escamas que atingem } \\
\text { o globo ocular causa (sic) coceira e } \\
\text { vermelhidão nos olhos reação } \\
\text { semelhante a quando tem um cisco ou } \\
\text { uma poeira nos olhos. }\end{array}$ \\
\hline
\end{tabular}


quando, muitas vezes, suas asas refletem a luz e produzem efeitos metálicos, que lembram as cores do arco-íris.

Quer uma receita para ter sempre borboletas voando livres por perto de você? Cultive um pequeno jardim de flores - seja no quintal, na varanda ou mesmo em um vasinho que possa ficar ao ar livre. Pode ter certeza de que elas vão aparecer para provar do néctar das flores - nessa visita, acabam também por poliniza-las também - e encher o seu jardim de beleza.

Fonte: Elaborado pelas autoras.

\section{Quadro 4: exemplos de repetições na produção textual da aluna Jamile}

Gostar ou não de banana é uma opção nossa, mas fazer a fruta sem sementes é uma obra rara da natureza que o ser humano percebeu e soube aproveitar e produzir bananas agradáveis ao seu paladar. É isso aí! A banana, ou melhor, a maioria das bananas cultivadas essas que a gente compra na feira ou no supermercado - não tem semente. Opa! Então como é que faz para brotar uma bananeira nova? Para usar um termo moderno da biologia, diremos que toda bananeira cultivada é um clone, ou seja, é uma planta idêntica à sua planta-mãe. $E$ antes que alguém pergunte: aqueles pontinhos pretos da banana são óvulos não fecundados, isto é, que não se desenvolveram em sementes. Agora, vejamos...

A bananeira pertence à família das Musáceas, cujos membros possuem um caule subterrâneo cheio de escamas, chamado rizoma, que é o verdadeiro e único caule da bananeira. Aquela parte verde que vemos e que aparenta ser o caule é, na realidade, um conjunto de camadas das folhas, umas dentro das outras, que brotam do rizoma. Pois, então, é a partir desse caule subterrâneo que nasce uma planta nova!

Em outras palavras, toda bananeira cultivada é obtida exclusivamente a partir de mudas do rizoma de outra planta - em alguns lugares, a muda é conhecida como "olho da bananeira".

Existem muitos tipos de bananas cultivadas assim: maçã, prata, ouro, da-terra, nanica... Todas elas recebem o nome científico de Musa x paradisíaca $L$., sendo a letra " $x$ " uma referência ao fato de serem cruzamentos de espécies diferentes. Esses cruzamentos são necessários para tornar as bananeiras mais resistentes a pragas e doenças e possibilitar o cultivo em grande escala.

Como dissemos lá no começo do texto, as bananeiras são raras. Muitas bananeiras selvagens apresentam sementes duras, que ocupam boa parte da massa comestível do fruto e, por isso, não são ideais para o comércio, sendo utilizadas no cruzamento das bananas cultivadas ou ornamentais.
Eu entendo que toda a banana não tem semente porque toda bananeira cultivada é um clone ou seja é uma planta idêntica à sua planta mãe, os pontinhos pretos que tem na banana são óvulos não fecundados, que não se desenvolve em sementes, a banana pertence a família MUSÁCEAS, que cujo os membros possuem um caule subterraneo cheios de escamas, chamado rizoma que é o unico verdadeiro caule da bananeira, a parte verde que vemos na banana é possuida por um monte de camadas das folhas, umas dentro das outras que brotam do rizoma, pois então entendi tambem que a partir deste caule subterraneo nasce uma planta nova.

Fonte: Elaborado pelas autoras. 
A partir dos Quadros anteriores (3 e 4) notamos que as PE1 possuem mais paráfrases do que polissemias. A maior parte das repetições estão no que Orlandi (1983) chama de repetições mnemônicas e formais. Como exemplo de repetição mnemônica, pouco encontrada na PE1 de Henrique, temos: "as escamas que atingem o globo ocular causa (sic) coceira e vermelhidão nos olhos reação semelhante a quando tem um cisco ou uma poeira nos olhos”. Já quando o aluno explica o "mito" de se tocar uma borboleta e depois coçar os olhos, ele acaba falando com suas próprias palavras (acrescentando algumas ou suprimindo outras), o que estava presente no TDC, caracterizando, assim, repetições formais: "não é tão perigoso assim”; “... é uma irritação simples que se resolve ao lavar os olhos com água bem limpa". Finalmente, apenas encontramos no resumo do texto de Henrique um fragmento que consideramos uma repetição histórica, quando ele explica o que são microescamas, informação esta que não se encontra no TDC original: "ou seja escamas muito pequenas". De uma forma geral, percebemos que o texto de Henrique é uma mescla de repetições mnemônicas e formais, ou seja, ele constrói um texto basicamente parafrásico. É importante também frisar que há um silêncio na PE1 de Henrique com relação aos dois últimos parágrafos do TDC que sequer são comentados em seu texto.

A PE1 de Jamile é, basicamente, parafrásica na qual encontramos apenas repetições mnemômicas e formais. Como exemplos das primeiras, mais recorrentes, temos: "toda bananeira cultivada é um clone, ou seja, é uma planta idêntica à sua planta mãe, os pontinhos pretos que tem na banana são óvulos não fecundados, que não se desenvolve em sementes [...]”. Apesar dos vários erros ortográficos e gramaticais que a aluna comete ao escrever seu texto, podemos perceber facilmente os trechos dessas repetições. Com relação às repetições formais, a aluna apenas reelabora a explicação original - mantendo o mesmo sentido - no fragmento: “(a) parte verde que vemos na banana é possuida (sic) por um monte de camadas das folhas, umas dentro das outras que brotam do rizoma". Jamile não chega a atingir o que Orlandi (1983) denomina de repetição histórica quando levamos em consideração o que é dito, considerando a ausência de polissemia.

A partir dessa análise em que buscamos interpretar o objeto discurso (PE1) a partir de uma aproximação dos textos que serviram como leitura base para sua elaboração, observamos que os dois alunos privilegiam repetições mnemônicas e formais de modo que a autoria, conforme ORLANDI (1996) concebe, não é concretizada devido a não historicização do dizer. Desta forma, algumas questões vêm à tona: será que os alunos que não realizaram repetições históricas não compreenderam os textos e, consequentemente, não se apropriaram dos conhecimentos científicos presentes nos TDC? O fato de os alunos não terem feito deslocamentos de sentidos é suficiente para que nós, analistas de discurso, afirmemos que apenas pela cópia ou reescrita os alunos não entenderam as explicações sobre os fenômenos científicos? Pistas para responder essas duas 
perguntas podem ser encontradas nas questões elaboradas para o jogo, no grau de dificuldade que elas assumem ou não.

Outro ponto importante de ser frisado diz respeito aos objetivos iniciais do professor ao solicitar as produções escritas (para virem a compor um jogo e, posteriormente, uma avaliação) e ao seu objetivo primeiro que é a promoção da autonomia. Neste caso específico, acreditamos que em parte os objetivos são atendidos porque os alunos tiveram acesso a conhecimentos científicos diversos, buscaram assuntos de seu próprio interesse (nesse sentido a autonomia é propiciada em algum nível), além de serem estimulados a ler e a escrever. Por outro lado, os alunos não autoraram seus próprios textos - conforme posto pela $\mathrm{AD}$ - o que acaba não contemplando a tal autonomia visada pelo professor. Porém, é importante relacionar a natureza da atividade proposta que, assim como a maioria das que são privilegiadas nas aulas de ciências, não era em si propiciadora da constituição de autores.

Ao focalizarmos as PE 2 e PE 3 dos dois alunos, levamos em consideração os contextos que constituíram condições de produção para cada um deles e determinaram tanto forma quanto conteúdo. Assim sendo, entendemos que as alterações verificadas nas PE2 e PE3 estão relacionadas ao processo de recontextualização discursiva que assume diferentes objetivos de acordo com cada uma das etapas da metodologia de ensino. A PE2 está inserida no contexto de um jogo de perguntas e respostas, logo, tem que ter um caráter mais desafiante e ao mesmo tempo, algo que fornece alguma base para os alunos que não leram o texto sejam capazes de responder através de raciocínio, de elaboração de hipóteses.

Nas produções de Henrique (Quadro 1), suas questões da PE1 não demandam conhecimentos científicos apurados e quase podem ser consideradas como sendo de "curiosidade geral”. Desta forma, quando passam pela primeira reelaboração discursiva para constituírem a pergunta do jogo que será exposta à turma (PE2), o professor valoriza uma informação que estava presente no resumo da reportagem feito pelo aluno (nesta questão a ênfase passa a ser a relação entre características morfológicas e a classificação taxonômica das borboletas). Quando esta questão passa a ser incluída no contexto de uma avaliação formal (PE3), o professor retoma a primeira pergunta feita pelo aluno na PE1, porém a reelabora atribuindo maior peso à questão da anatomia do animal (microescamas nas asas) relacionada àquilo que no, final das contas, é o tema central do TDC que é a consequência de se tocar uma borboleta e, em seguida, levar as mãos aos olhos.

Finalmente, no caso da Jamile (Quadro 2), a primeira questão da PE1 está ainda muito "presa" à leitura do TDC (vimos que há vários trechos parafrásicos que se remetem a uma repetição mnemônica) e provavelmente só seria respondida corretamente pelos demais alunos (que não leram 
o TDC) na base do palpite não fundamentado. Nesse sentido, a reelaboração feita pelo professor ocorre de modo que os alunos consigam obter a informação chave da questão através da própria pergunta e ainda destaca um aspecto importante do texto que não havia sido contemplado na PE1 da aluna: a reprodução por clonagem. Na PE3, temos uma pergunta de avaliação escrita, que os alunos têm que responder com base apenas naquilo que lembram da atividade do jogo e do material escrito confeccionado pelo professor para eles estudarem para a prova. Então, o professor acaba tendo que modificar a pergunta, não apenas para se certificar de que o aluno entendeu e não só “decorou” qual foi a resposta certa do jogo, mas também para garantir que o aluno seja capaz de responder com base nas informações anteriormente disponibilizadas. Desta forma, mesmo que um aluno não tenha feito a revisão do material entregue pelo professor, basta que ele tenha prestado o mínimo de atenção no jogo para recordar que o texto que a colega leu falava de banana e não de laranja ou goiaba.

\section{Algumas novas reflexões e considerações finais}

Compreendemos que as experiências enquanto aluno da educação básica e, mais especificamente, as histórias de leitura e escrita do professor Ézio, constituem condições de produção de seu atual discurso sobre a Educação em Ciências. Entendemos que suas experiências anteriores de leitura e de escrita e de formação escolar e acadêmica levaram-no a assumir como principal objetivo do ensino de ciências a autonomia de seus alunos e, ao mesmo tempo, afirmar sua preocupação com a formação de leitores e escritores no espaço de suas aulas. A partir disso, podemos compreender algumas das motivações para o desenvolvimento e a aplicação da metodologia de ensino "Roda do conhecimento" em aulas de ciências do ensino fundamental.

Buscamos neste artigo descrever a "Roda do conhecimento" em cada uma de suas etapas e, indo mais além, perceber se esta prática de ensino de fato contribui para a constituição de leitores e, sobretudo, autores nas aulas de ciências, pautada na promoção do letramento científico. Por meio da análise de textos produzidos por dois alunos, focalizamos nas reproduções (paráfrases) e nos deslocamentos de sentidos (polissemias) efetuados pelos sujeitos escritores em diferentes situações. Desta forma, identificamos nas produções escritas (derivadas das solicitações e/ou modificações feitas pelo próprio professor a partir da leitura inicial de textos de divulgação científica da revista CHC) diferentes níveis de repetição que puderam nos sinalizar a constituição de autores (ORLANDI, 1983).

Pudemos observar que os alunos constituíram repetições formais em seus textos, com ênfase na paráfrase. Este resultado poderia levar-nos à compreensão de que os sujeitos não conseguiram autorar por não terem produzido textos com polissemias e, assim, alcançado repetições 
históricas. Desta forma, eles não teriam alcançado o letramento científico dentro de uma perspectiva de apropriação pessoal dos conceitos científicos. No entanto, gostaríamos de fazer uma reflexão que nos parece pertinente através das seguintes questões: será que os alunos que não realizaram repetições históricas não compreenderam os TDC e, consequentemente, não se apropriaram dos conhecimentos científicos presentes nestes textos? O fato de os alunos não terem feito deslocamentos de sentidos é suficiente para que nós, analistas de discurso, afirmemos que apenas pela cópia ou reescrita os alunos não entenderam as explicações sobre os fenômenos científicos? Entendemos que podemos nos aproximar de possíveis respostas a estas questões quando relativizamos os diferentes níveis de repetição (mnemônica, formal e histórica) no âmbito do ensino formal de ciências, uma vez que se torna difícil avaliar a inscrição dos conceitos nas memórias discursivas dos sujeitos por meio das produções escritas resultantes das atividades propostas pelo professor aqui analisadas.

No processo de análise (interpretação) das produções escritas dos alunos sob o enfoque na forma do dizer e no deslocamento dos sentidos em relação aos conhecimentos científicos, concluímos que os alunos realizaram basicamente repetições mnemônicas e formais. Consideramos, no entanto, que essa tendência está relacionada a uma peculiaridade do discurso científico escolar. Segundo Christensen e Fensham (2012), a ciência escolar tradicional está baseada em um corpo de conhecimentos já bem estabelecidos e consolidados e sua aprendizagem envolve a reprodução desse conhecimento estático e de princípios que conduzem a uma única resposta correta. Dentro desse contexto de conhecimentos estáticos e de princípios que conduzem a uma única resposta correta, não há espaço para uma ampla polissemia, mas sim para um processo de restrição dos sentidos, característico do discurso pedagógico escolar que é classificado por Orlandi (1983) como discurso autoritário. Como nos apontam Tfouni e Assolini (2008), a interpretação no discurso pedagógico escolar consiste em reafirmar e reproduzir os conteúdos que a escola, enquanto instituição, julga serem importantes para o aluno. Nesse sentido, no contexto do discurso científico escolar, também não é qualquer sentido que pode ser dado aos conceitos científicos, mas aqueles sociohistoricamente estabelecidos como relevantes para a ciência escolar e para sua manutenção.

Entendemos que, devido a essas características do discurso científico escolar, ao analisar especificamente o conhecimento científico expresso pelos alunos a partir da leitura de TDC da revista $\mathrm{CHC}$, encontramos repetições que tendem a ser formais sob o aspecto de deslocamento de sentidos e de forma do dizer. No entanto, outro aspecto da repetição é a questão da memória do dizer. $\mathrm{O}$ aluno pode ter dito uma mesma coisa a respeito de determinado conhecimento científico da mesma forma que o professor (repetição empírica ou mnemônica) ou através de reformulação de frases (repetição formal ou técnica) sem realizar, necessariamente, um deslocamento de sentidos em 
relação a esse conhecimento e, ainda assim, ter mergulhado esse dizer em sua memória discursiva (repetição histórica), ou seja, aquilo que é dito pelos alunos em relação ao conhecimento científico, os conceitos e explicações científicas que elaboram, são meras reformulações de um dizer (o do professor), o que constitui um dos aspectos relacionados à repetição chamada de formal ou técnica e que se contrapõe à repetição histórica - que produziria um deslocamento de sentidos. Mas, mesmo reformulando um mesmo dizer, sem produzir um novo sentido para os conhecimentos científicos, esse aluno pode estar inscrevendo esse dizer em sua memória discursiva, produzindo uma história para esses sentidos já postos, o que também é um dos aspectos da repetição histórica.

Desta forma, entendemos que a metodologia de ensino "Roda do conhecimento", apesar de ter tido em sua própria concepção a questão da autonomia do sujeito (que permitiria ao aluno colocar-se diante do TDC e, assim, constituir-se como autor letrado cientificamente), está, por si só, limitada às fronteiras pré-estabelecidas do discurso científico escolar. Isto não significa dizer que atividades que incentivam os processos de leitura e de escrita em aulas de ciências não são válidas. Ao contrário, reconhecemos a importância destas inovações didáticas no sentido de trazer para a sala de aula de ciências textos de diferentes gêneros e, com isso, exercitar diferentes habilidades de leitura e de escrita dos alunos. Porém, ressaltamos que todas elas possuem limitações uma vez que se encontram inscritas em uma forma de dizer altamente estável do ponto de vista discursivo, em uma formação discursiva relacionada à autoridade do discurso científico que é reforçada nas aulas de ciências por meio da restrição dos efeitos de sentidos. Resta-nos continuar realizando investigações empíricas que nos permitam refletir, teoricamente, sobre o quanto queremos e devemos ampliar as possibilidades de interpretações de textos relacionados ao discurso científico, visando ao letramento científico dos alunos da educação básica.

\section{Referências}

ALMEIDA, M. J. P. M. de; OLIVEIRA, O. B. de.; CASSIANI, S. Leitura e escrita em aulas de ciências: Luz, calor e fotossíntese nas mediações escolares. Florianópolis, SC: Letras Contemporâneas, 2008.

BAKHTIN, M. Estética da criação verbal. São Paulo: Martins Fontes (Coleção Ensino Superior), 1992.

CHRISTENSEN, C.; FENSHAM, P. J. Uncertainty and complexity in science education. In: FRASER, Barry J.; TOBIN, Kenneth G.; MCROBBIE, Campbell J. (Eds.). Second International Handbook of Science Education. London; New York: Springer, 2012.

KRASILCHIK, M. Reformas e realidade: o caso do ensino das ciências. São Paulo em Perspectiva, v. 14, n. 1, p. 85-93, 2000.

FERREIRA, C. S. C.; GALIETA, T. Relações entre leitura, escrita e alfabetização/letramento científico: um levantamento bibliográfico em periódicos nacionais da área de ensino de ciências. Ciência \& Educação, v. 21, p. 991-1009, 2015. 
Revisão de literatura em periódicos nacionais: a produção sobre letramento científico, leitura e escrita. Revista de Ensino de Biologia da Associação Brasileira de Ensino de Biologia (SBEnBio), v. 7, p. 1241-1252, 2014.

GALIETA, T. Formações discursivas em textos de livro didático e de divulgação científica. In: GALIETA; T; GIRALDI, P. M. (Orgs.). Linguagens e Discursos na Educação em Ciências. Rio de Janeiro: Editora Multifoco, 2014, p. 205-222.

GALIETA-NASCIMENTO; REZENDE JUNIOR. A produção sobre divulgação científica na área de educação em ciências: referenciais teóricos e principais temáticas. Investigações em Ensino de Ciências, v. 15, p. 97-120, 2010.

GIRALDI, P. M. Leitura e escrita no ensino de ciências: espaços para a produção de autoria. Tese (Doutorado em Educação Científica e Tecnológica). Florianópolis: UFSC, 2010.

MARANDINO. M.; SELLES, S. E.; FERREIRA, M. S. Ensino de Biologia: histórias e práticas m diferentes espaços educativos. São Paulo: Cortez, 2009.

MINAYO, M. C. de S. Trabalho de campo: contexto de observação, interação e descoberta. In: . (Org.). Pesquisa social: teoria, método e criatividade. 32. ed. Petrópolis, RJ: Vozes, 2012.

ORLANDI, E. P. Análise de discurso: princípios e procedimentos. Campinas: Pontes, 2002. 1996. Interpretação: autoria, leitura e efeitos do trabalho simbólico. 2. ed. Petrópolis, RJ: Vozes,

Discurso e leitura. 2. ed. São Paulo: Cortez, 1993.

As histórias das leituras. Leitura: teoria \& prática. Porto Alegre: Mercado Aberto, Ano 3, p. 7-9, jul. 1984. 1983.

. A linguagem e seu funcionamento: as formas do discurso. São Paulo: Editora Brasiliense,

PÊCHEUX, M. O discurso: estrutura ou acontecimento. Campinas, SP: Pontes, 1990.

SANTOS, W. L. P. dos. Scientific literacy: a Freirean perspective as a radical view of humanistic science education. Science Education, v. 93, n. 2, p. 361-384, 2009.

. Letramento em química, educação planetária e inclusão social. Química Nova, v. 29, n. 3 , p. 611-620, 2006.

TFOUNI, L. V.; ASSOLINI, F. E. P. Interpretação, autoria e prática pedagógica escolar. Odisséia (UFRN), n. 1, p. 1-16, 2008.

ZAMBONI, L. M. S. Cientistas, jornalistas e a divulgação científica: subjetividade e heterogeneidade no discurso da divulgação científica. Campinas, SP: Autores Associados, 2001.

\section{Agradecimentos}

Ao professor, sujeito desta pesquisa, por ter participado da entrevista e compartilhado conosco suas vivências pessoais e profissionais.

Ao CNPq e à CAPES pelo auxílio financeiro e bolsa de mestrado, respectivamente, que permitiram o desenvolvimento da pesquisa.

Submetido em setembro de 2016 Aprovado em outubro de 201 